\title{
Ecological effects and perceptions of victims of pipeline explosion in a developing country
}

\author{
E. O. Omodanisi · A. O. Eludoyin · A. T. Salami
}

Received: 21 December 2012/Revised: 23 November 2013/ Accepted: 17 March 2014/Published online: 10 April 2014

(C) Islamic Azad University (IAU) 2014

\begin{abstract}
Petroleum pipeline network is a critical infrastructure that should be protected because of its importance and the danger of fire disaster and ecosystem disruption if unprotected. However, the procedure for the management of the pipeline in Nigeria is probably faulty, and we think that this accounts for the multiple occurrences of pipeline fires in Nigeria between 1998 and 2007. Our study involves the use of satellite imageries, ecological sampling, questionnaire and personal interaction with some of the victims of the December 2006 pipeline fire in Ilado-Odo community in Lagos State, Nigeria. We attributed the causes of pipeline fires to poor pipeline network monitoring, poor communication and transportation in the vulnerable communities, and the inability of the pipeline management agency to ensure adequate community participation. We found that the biotic and abiotic components of the IladoOdo community were severely impaired, and we think that the impact may last for a long time if there is no postdisaster recovery programme. We conclude that the present method of labour-intensive approach to pipeline monitoring in Nigeria can promote further development of organised crime as explained by the Queer Ladder concept. We therefore recommend better tracking system, enhanced
\end{abstract}

E. O. Omodanisi · A. T. Salami

Institute of Ecology and Environmental Studies, Obafemi

Awolowo University, Ile-Ife, Nigeria

A. O. Eludoyin

Department of Geography, Obafemi Awolowo University, Ile-Ife, Nigeria

A. O. Eludoyin $(\bowtie)$

Department of Geography, CLES, University of Exeter, Rennes

Road, Exeter, Devon EX4 4RJ, UK

e-mail: oaeludoyin@yahoo.com communication and transport infrastructure, as well as the review of the existing right-of-way regulations, and their strict enforcement around all critical infrastructures.

Keywords Critical infrastructure - Pipeline fires . Ecological effects $\cdot$ Multi-perspective analysis

\section{Introduction}

Recently, protection of critical infrastructure has become important concerns for governments in many countries, because the infrastructures are often targets of attacks (De Bruijne and Van Eeten 2007; Seidl and Simák 2012). Critical infrastructure includes telecommunications, water supply, transportation, gas and oil storage and transportation facilities, whose incapacity or destruction can result to social or financial insecurity in any area (Clinton 1996). Petroleum pipelines networks are a critical infrastructure and can be targets of terrorists' attacks and economic sabotage (van den Berg and Mbara 2011; Acosta et al. 2013). Failures of petroleum pipelines are known to have caused environmental pollution and deaths of plants, animals and humans (White 2006; De Bruijne and Van Eeten 2007; Fadeyibi et al. 2011; van den Berg and Mbara 2011; Acosta et al. 2013).

Nigeria is the largest producer of crude oil (maximum crude oil production capacity is 2.5 million barrels per day) in Africa, and sixth in the world (Nigerian National Corporation, NNPC, 2013). The Pipelines and Products Marketing Company Limited, PPMC, which is business unit of the NNPC, is responsible for the monitoring and maintenance of the over $5,120 \mathrm{~km}$ petroleum pipeline networks in Nigeria (http://ppmc.nnpcgroup.com). The many cases of vandalisation of the pipeline for oil theft and sabotages, however, 
suggest that the management of the pipelines is quite problematic (White 2006; Adeniyi 2007; Fadeyibi et al. 2011; Okoli et al. 2013). In places where petroleum pipelines are vandalised in Nigeria, fire often erupt, probably as a result of ignorant exposure to a source of fire or from the pressure of its discharge. Almost all the reported cases of pipeline explosions recorded in Nigeria were attributed to deliberate rupture by oil thieves or saboteurs (Fadeyibi et al. 2011; van den Berg and Mbara 2011). Vandalising the petroleum pipelines as an act of sabotage was particularly important in Nigeria until recently, when most saboteurs of the petroleum pipelines in the Niger Delta of Nigeria have been granted amnesty by the Nigerian government (Adegboyega and Adesola 2013; Osumah 2013). The amnesty programme allowed the saboteurs and other armed strugglers in the Niger Delta to surrender their weapons in exchange for freedom from prosecutions and other benefits from the Nigerian government (Isumonah 2013). On the other hand, pipeline vandalisation due to oil theft still occurs in the communities where the petroleum pipeline network passes. Omeje (2005) and Adeniyi (2007) among other authors have attributed the causes of petroleum pipelines in Nigeria to corrupt practices, negligence of responsibility and bureaucratic bottlenecks that often delay responses to early warning and limit the sincerity of the workers to protect the infrastructure. Another group of authors (Idemudia and Ite 2007; Onuoha 2009; Okoli et al. 2013) assumed that the petroleum pipeline vandals often do it because of some socio-economic challenges (including unemployment). The socio-economic perspective to understanding the incidences of pipeline vandalisation in Nigeria was also explained by Okoli et al (2013) in terms of the concept of the Queer Ladder (QL) (Layman and Potter 2007). The QL concept assumes that vandalisation of petroleum pipelines in Nigeria is a product of an organised crime, which is usually perceived as an instrument of social climbing, socio-economic advancement and a means to accumulate wealth and build power by those involved.

Vandalised petroleum pipelines are known to cause oil leakages and spills, which have resulted in contamination of land and water resources, accumulate in animals and plants, forced people out of their previously productive land resources and caused ecological instability and ultimately deaths of plants, animals and humans (Imevbore and Odu 1985; Isichei and Ero 1987; Ikporukpo 1988; Egharevba and Osunde 2001; Jike 2004; Asumi 2009; Wunder 2005; Incardona et al 2010). In many cases, oil leakages have caused fire disasters and have killed many humans and destroy their livelihood. In Nigeria, at least 15 cases of petroleum-pipeline-related fire disasters have been recorded between October 1998 and December 2007 (Fadeyibi et al. 2011; Okoli et al. 2013). The severest of the fire disaster was recorded at Jesse in the Niger Delta in October 1998, which killed at least 1,200 people. About nine (in the years 2000, 2004, 2005, 2006 and 2007) of such fire disaster have also occurred in the rural parts of Lagos State, with varied number of victims. Amuwo-Odofin local government area (LGA) in Lagos State experienced pipeline fire disaster at four different times between 2005 and 2006, each recording a number of casualties.

In spite of the different views of the causes and effects of the pipeline explosion fires on humans, their livelihoods and environment, information about the ecological effects and the perceptions of the victims of such tragic events are relatively unknown. The poor knowledge of the causes and effect stemmed from the fact that most materials available are from newspapers and are often biased (e.g. White 2006; Adeniyi 2007). Many other studies have also focussed on laboratory analysis or literature review and do not often represent the real life experience in the fields and the perceptions of the victims or witnesses of such disasters (e.g. Imevbore and Odu 1985; Egharevba and Osunde 2001; Jike 2004; Asumi 2009; Anifowose et al. 2011; Fadeyibi et al. 2011). We therefore have followed the recommendations of Smith and Loza (1994) that the ability to combine data from digital and social surveys, laboratory readings and spatial information in a geographical information system is adequate for effective environmental management to conduct this study. Specific objectives of this study were to examine as a case study, the causes and ecological effects of a petroleum pipeline explosion in Nigeria from geographic information system, ecological and social surveys approaches. Selected case study is the pipeline fire disaster of 26 December 2006, which killed more than 256 people and significantly degraded the ecological system of the IladoOdo community in Lagos State, Nigeria. We would have preferred to study the events at Jesse, Niger Delta, where more people were killed in pipeline fire disasters in 1998 and 2000, but we consider it dated. We also could not visit the site of the Jesse disaster because of the security challenge in the Niger Delta at the time of this study.

\section{Study area}

Ilado-Odo community is a rural community in Lagos State, Nigeria (Fig. 1), and it is located on $6^{\circ} 25^{\prime} \mathrm{N} 3^{\circ} 21^{\prime} \mathrm{E}$. IladoOdo was a quiet and relatively unknown community in 'Ward J' of Amuwo-Odofin LGA, until the pipeline explosion occurred. The people, however, settle in clans (Sanke, Okun Glass, Inuegbe and Idimagoro), typical of many rural African settlements (Lindley 2013; SanchezFaddeev et al. 2013). Ilado-Odo community can be regarded as a remote rural area because it is only accessible from the nearest community by water transport and does not have access to landline telephone; although there is limited wireless phone coverage, only the few educated people could afford to use them. The community also lacks 


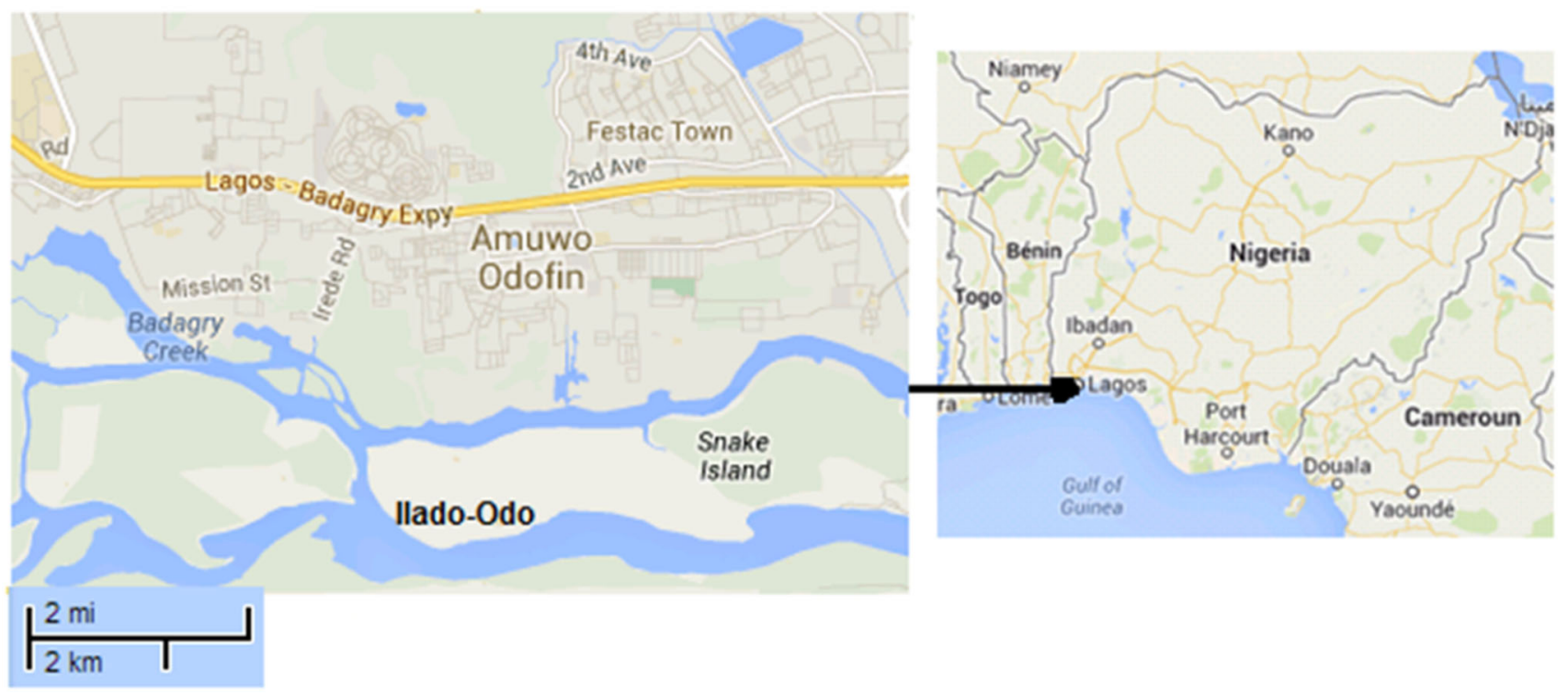

Fig. 1 Map showing the location of Ilado-Odo community in Nigeria. Ilado-Odo is in Ward J of Amuwo-Odofin local government area in Lagos State, Nigeria. Maps were taken from Google Earth

pipe-borne water and good means of human waste disposal. There was also no electricity supply and healthcare provider at the time of this study, but few schools (primary and secondary schools) exist. Problem with poor accessibility to basic infrastructure in Ilado-Odo community is probably a common issue to many rural communities in Nigeria (Allen 2013); even as over $70 \%$ of the urban populations in Africa are known to lack good housing and sanitation facilities (Cairncross 1989; Moe and Rheingans 2006).

Nigeria can be classified into three climate types (tropical rainforest, tropical savanna and montane climates), and IladoOdo community exhibits the tropical wet type of tropical rainforest climate (Dada et al. 2008). The tropical wet climate is a subgroup of the 'Af' climate of the Koppen's climate classification scheme, and it is characterised by annual small temperature range (mean \pm standard deviation $=27.3 \pm 1.2^{\circ} \mathrm{C}$ ) and high humidity (mean \pm standard deviation $=85.1 \pm$ $5.0 \%$ ) (Eludoyin et al. 2013). The vegetation is entirely mangrove or swamp forest, although a significant portion has been lost to arable farming. Monthly rainfall values exhibit significant seasonal (dry and wet) variations and can vary between 200 and $350 \mathrm{~mm}$ in a year (Iloeje 1981).

\section{Materials and methods}

We approached this study from three major perspectives: (1) social survey or questionnaire method, (2) image classification and GIS, and (3) ecological investigations. (1) Questionnaire was administered to a randomly selected group of people and collected in June and July 2007.
Random sampling technique was adopted because the hitherto planned stratified sampling had failed as a consequence of the effect of the pipeline explosion disaster that forced the inhabitants to leave their houses. Subsequently, only fewer than 200 copies of questionnaire were returned, out of the entire 350 copies distributed with the initial plan of stratified sampling in mind. We had planned the questionnaire administration using the Slovin principle, which suggest that

Sample population $=\frac{N}{1+N e^{2}}$

where $N=$ total targeted population, $e=$ confidence level (0.05 for $95 \%)$.

The questionnaire was structured such into two main parts; (1) information about the gender, age, occupation and other socio-economic status of the respondent. This information was to be used to inspect the possible bias in the perception of the respondents, and (2) perception on the causes and effects of the pipeline explosion of 26 December 2006. There were close-ended questions, and a number of open-ended questions to allow the respondents free response. Completed copies of questionnaire were collected after continuous visit of the study area, within the period that the ecological sampling was made. All the responses were coded and summarised with descriptive analysis using the IBM SPSS software (IBM 2011). Effect of differences in the education, age, gender and economic status of the respondents on the overall perception was examined for each question using the analysis of variance (ANOVA). The essence of this examination is to identify bias based on the different socio-economic and demographic status of the respondents. 
Table 1 Some demographic and socio-economic characteristics of sample population in Ilado-Odo community, Amuwo-Odofin LGA, Lagos, Nigeria $(n=200)$

\begin{tabular}{llrr}
\hline Variables & Options & $N$ & $\%$ \\
\hline Sex & Male & 135 & 67.5 \\
Occupation & Female & 65 & 32.5 \\
& Civil servant & 34 & 17.8 \\
& Student & 48 & 25.1 \\
& Driver & 14 & 7.3 \\
& Farmer & 14 & 7.3 \\
& Trader/business & 64 & 33.5 \\
& Artisan & 17 & 8.9 \\
Monthly income (in Naira $\left.{ }^{a}\right)$ & $<$ N10,000 & 33 & 19.5 \\
& $10,000-20,000$ & 41 & 24.3 \\
& $21,000-30,000$ & 42 & 24.9 \\
& 31,000-40,000 & 27 & 16.0 \\
& $\geq 40,001$ & 26 & 15.4 \\
Education & Primary & 25 & 12.5 \\
& Secondary & 77 & 38.5 \\
& Tertiary & 52 & 26.0 \\
& Vocational & 20 & 10.3 \\
Total in each variable & None & 20 & 10.3 \\
& & 200 & 100 \\
\hline
\end{tabular}

${ }^{a} \$ 1=\mathrm{N} 159.55$ as at the time of the research

(2) The geographical information analysis was undertaken to evaluate the vulnerability of the affected settlements and assess the effect of the explosion on the land cover from composite imageries. Imageries examined were acquired from a Landsat Enhanced Thematic Mapper Plus (2005 Landsat ETM+) and IKONOS (2007), and these imageries were compared to examine the change in landcover appearance in 2005 before the pipeline explosion and in 2007, a year after the explosion. Landsat ETM+ is a Landsat (Satellite Programme of the National Aeronautics and Space Administration (NASA), http://landsat.gsfc.nasa.gov/) that have been considered useful for monitoring tropical forests at a relatively high spatial [ 15 by $15 \mathrm{~m}$ (for panchromatic), 30 by $30 \mathrm{~m}$ (visible colour), 60 by $60 \mathrm{~m}$ (thermal)] resolution, with at least six spectral bands (Feeley et al. 2005). This was used because it was free to acquire at the NASA website. The IKONOS imagery was acquired with the assistance of the Space and Environmental Laboratory at the Institute of Ecology and Environmental Studies, Obafemi Awolowo University, Ile-Ife, Nigeria (SPAEL, http://www.spaeloauife. net/). IKONOS satellite was launched in 1999 by space imaging (SI), and it maps earth images at about 5.8-m spatial resolution; it has also been confirmed to be suitable for the ecological time (Thome 2001; Li et al. 2007).

The entire satellite imageries were georeferenced using points or benchmarks that have been confirmed with a hand-held global positioning system (GPS) (Magellan
Table 2 Perception on the causes of the December 2006 pipeline explosion at Ilado-Odo community and recommendations by the respondents $(n=200)$

\begin{tabular}{|c|c|c|}
\hline Questions & $\begin{array}{l}\text { Response } \\
\text { type }\end{array}$ & Responses (\%) \\
\hline $\begin{array}{l}\text { 1. What do you think } \\
\text { caused the pipeline } \\
\text { explosion? }\end{array}$ & $\begin{array}{l}\text { Open } \\
\text { ended }\end{array}$ & $\begin{array}{l}\text { Exposed pipeline due to } \\
\text { erosion and age ( } 45 \%) \\
\text { Activities of vandals } \\
(61 \%) \\
\text { No community-based } \\
\text { security team to monitor } \\
\text { the pipeline since police } \\
\text { team were not always } \\
\text { available ( } 39 \%) \\
\text { Some community } \\
\text { members because of } \\
\text { their greed or poverty } \\
\text { also siphoned the } \\
\text { leaking oil }(26 \%)\end{array}$ \\
\hline $\begin{array}{l}\text { 2. Why did the pipeline } \\
\text { leak for long without } \\
\text { being reported before the } \\
\text { explosion? }\end{array}$ & $\begin{array}{l}\text { Open } \\
\text { ended }\end{array}$ & $\begin{array}{l}\text { We reported }(59.9 \%) \\
\text { I do not know if we } \\
\text { reported }(20.1) \\
\text { I do not know where we } \\
\text { should report to }(20 \%)\end{array}$ \\
\hline $\begin{array}{l}\text { 3. What do you think is the } \\
\text { best way to stop the } \\
\text { vandals and prevent } \\
\text { future occurrence? }\end{array}$ & $\begin{array}{l}\text { Open } \\
\text { ended }\end{array}$ & $\begin{array}{l}\text { Resuscitating the banned } \\
\text { local vigilante group } \\
(61 \%) \\
\text { Consistent monitoring } \\
(80 \%) \\
\text { Participatory monitoring } \\
\text { with the community } \\
\text { youths ( } 45 \%) \\
\text { Improved tracking system } \\
\text { for the pipelines }(49 \%)\end{array}$ \\
\hline
\end{tabular}

Multiple responses occurred for questions 1 and 3. There was no significant difference in the perceptions rate for each question by either gender, income group or level of education $(p>0.05)$

model; accuracy level is $\pm 10 \mathrm{~m}$ ). The imageries were then processed, classified and analysed using GIS software, particularly Erdas Imagine (9.2 version) and ILWIS (3.3 version) (ERDAS 1999; Gers and Schmidt 2001; van Western 2003). Using the approach, five broad landcover/ use classes (forest, water body, built up area, utilities and farmlands) were identified using the maximum likelihood algorithm in supervised classification procedure (Maselli et al. 1994). Furthermore, separate constant width buffers (of 25, 50, 100, $500 \mathrm{~m}$ and $1 \mathrm{~km}$ ) each were created around the pipeline, which was constructed by the NNPC to pass through Ilado-Odo community when the classified landcover imagery was converted to vector format and imported to ArcGIS (9.2) software, to complete the mapping process. Buffering or distance analysis (in vector format) refers to the creation of a zone of a specified width around a point or a line or a polygon area, and the zones or buffers can be used to determine which entities occur either within 
(a) $25 \mathrm{~m}$ buffer zone around the petroleum pipeline

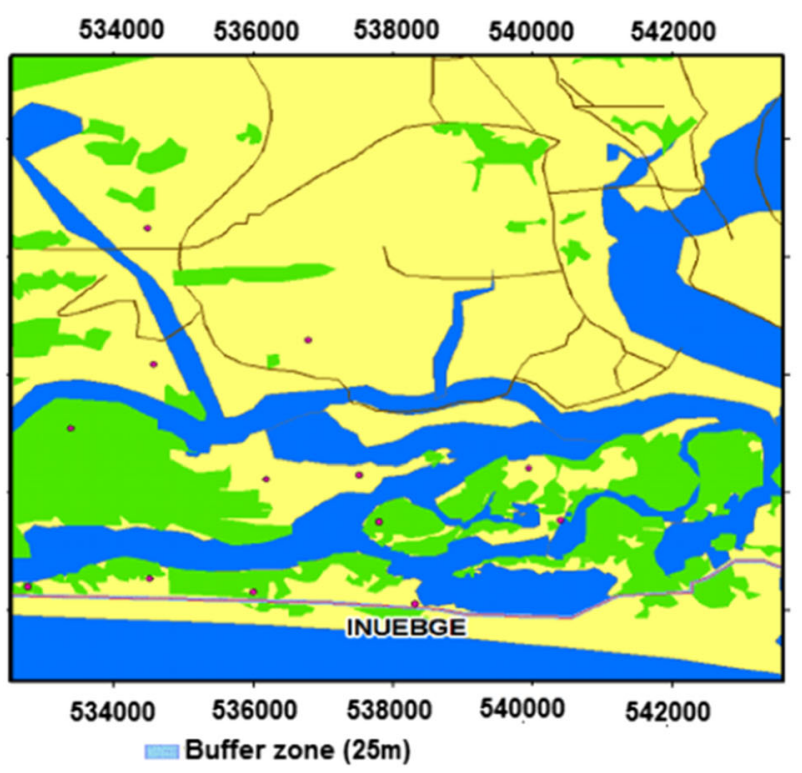

Fig. 2 Classified imageries of Amuwo-Odofin LGA, Lagos State, Nigeria, showing the relative locations of the clans in Ilado-Odo community to the pipeline corridor (June, 2005). 'Inuegbe' clan

or outside the defined buffer zone (Briggs et al. 2002). From the result of the buffering analysis, instances of incursion of land use into the pipeline corridor that was expected to be protected by the right-of-way (ROW) rules were determined. The Nigerian Oil Pipeline Act, NOPA (Chapter 338 LFN, 1990) established ROW around oil pipeline as $47.5 \mathrm{~m}$, where it is a crime for human activities to be found.

(3) Ecological investigations were conducted to determine the direct effect of the pipeline explosion on the vegetation around the clans in Ilado-Odo community. Nine quadrats $(10$ by $10 \mathrm{~m})$ were set within $500 \mathrm{~m}^{2}$ (adjacent to the oil pipeline corridor) of the impaired clans, and a 'control' quadrat (also 10 by $10 \mathrm{~m}$ ) was selected at about $2 \mathrm{~km}$ away from the affected location of the explosion as advised in the literature (Williams and Lambert 1959; Faith et al. 1987; Kleyer et al. 2012). From each quadrat, species richness (number of species in a community) was determined by identifying the plants in each quadrat to species level. Morphology of dominant woody species was determined in terms of their height $(0-0.10,0.10-20,0.20-0.30$ and $0.30-0.40 \mathrm{~m})$ and girth at breast height (gbh) $(0-2,2-4,4-6$ and $6-8 \mathrm{~m})$ as described in the literature (Bunce 1968; Thomas 1996). Species diversity was determined using Shannon-Weiner index $\left(H^{\prime}\right)$ (Eq. 2a).

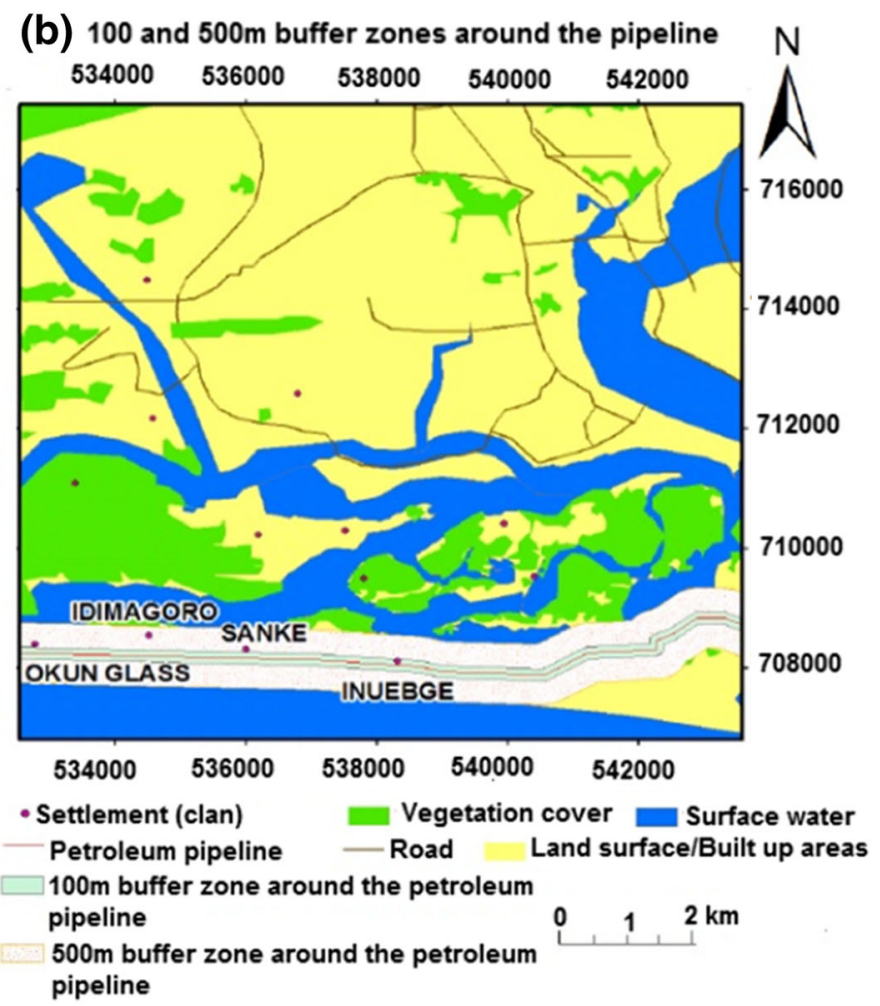

occurred within $25 \mathrm{~m}$ of the pipeline corridor; 'Sanke' and 'Okun Glass' are within the $100 \mathrm{~m}$ range and 'Idimagoro' occurred within the $500 \mathrm{~m}$ range of the pipeline corridor

$H^{\prime}=-\sum_{s=1}^{s} p_{s} \ln \left(p_{i}\right)$

$p_{i}=x_{s} \div \sum x$

$\sum x=\sum_{s=1}^{s} x_{s}$

$s=$ the number of $s$ species in the sample, $x_{s}=$ the abundance of $s$ th species, $p_{i}=$ is the proportion of each species in the quadrat.

The $H^{\prime}$ is a well-accepted measure of biodiversity in ecological studies (Smith and Wilson 1996). This entire study was conducted between June 2007 and 2008; about 6 months after the pipeline explosion had occurred.

\section{Results and discussion}

Perceptions on the causes of the 26 December 2006 pipeline explosion

The demography of the sampled population for questionnaire administration showed that majority of the respondents were traders and students (Table 1), and we think that the main settlers in Ilado-Odo community have been forced 
to emigrate since the fire disaster has destroyed their farms, which was their main source of livelihood. Many of the farmers have either relocated to the urban areas with their relatives or found different sources of livelihood, elsewhere. The results of the analysis of the questionnaire show that most of the respondents perceived that the investigated pipeline explosion was as a result of the activities of vandals $(61 \%)$ and the influence of erosion which exposed the location of the petroleum pipeline to vandals (45\%). While we agree that the exposure of a petroleum pipeline by erosion is a pointer to the fact that the management of pipeline was not properly taken care of, we also think that it is reasonable to link the cause of pipeline vandalisation in the study area to economic reasons.

Similarly, studies (e.g. Chokor 2004; Dawotola et al. 2010) have argued that faulty petroleum pipelines are not common problems in Nigeria, but they linked about $60 \%$ of the entire pipeline failure that have been recorded in Nigeria to sabotage, oil thefts and other forms of external interferences with the petroleum pipeline. In the study area, our discussion with the respondents (not provided for in the questionnaire) revealed that the pipeline had leaked for few days before the pipeline explosion. Although $59.9 \%$ of the respondents argued that the leaked pipeline was reported, but such result cannot be accepted in this study because our analysis of variance also showed that the responses varied significantly with the level of education of the respondents; our cross analysis showed that about $20.1 \%$ of respondents did not even know where to report such incidence to (Table 2).

Furthermore, the results of our buffering analysis showed that some of the clans (Inuegbe, Sanke and Okun Glass) in the study area existed in the 25 and 100 m radii of the pipeline corridor before the 26 December 2006 pipeline explosion (Fig. 2a, b). The clans within these buffer zones were utterly destroyed by the pipeline explosion. Although the spatial resolution of our satellite imageries did not reveal whether the pipeline corridor was cultivated before the pipeline explosion, we know that the Inuegbe clan contravened the right-of-way (ROW) rules in Nigeria (NOPA, Chapter 338, LFN 1990).

Perception on the effects of the pipeline explosion

Perceptions of the respondents on the effects of the 26 December 2006 pipeline explosion, in the study area, are presented in Table 3. The effects include degradation of the groundwater quality; more than $70 \%$ of the respondents voted that the water quality tasted bad and that the air quality has degraded. A study on groundwater sources (both deep boreholes and shallow well water) by Oyeku and Eludoyin (2010) showed that major landuse changes can cause severe contamination of the water resources, especially the shallow well water. This result is important
Table 3 Perception on the effects of the December 2006 pipeline explosion on the people of Ilado-Odo community in Amuwo-Odofin LGA, Lagos State, Nigeria $(n=200)$

\begin{tabular}{|c|c|c|}
\hline Question & Option & $\begin{array}{l}\text { Responses } \\
(\%)\end{array}$ \\
\hline \multirow{2}{*}{$\begin{array}{l}\text { 1. After the explosion, did } \\
\text { you notice any alteration } \\
\text { or change in the air, } \\
\text { water or farmland? }\end{array}$} & Yes & 82.8 \\
\hline & No & 17.2 \\
\hline \multirow{2}{*}{$\begin{array}{l}\text { 2. Did the taste of the well } \\
\text { water (groundwater) } \\
\text { change after the } \\
\text { explosion? }\end{array}$} & Yes & 78.9 \\
\hline & No & 21.1 \\
\hline \multirow{2}{*}{$\begin{array}{l}\text { 3. Do you think } \\
\text { vandalising the oil } \\
\text { pipeline is dangerous to } \\
\text { the community? }\end{array}$} & Yes & 98.5 \\
\hline & No & 1.5 \\
\hline \multirow{2}{*}{$\begin{array}{l}\text { 4. Are you aware that oil } \\
\text { leakage can affect } \\
\text { farmland, water and air } \\
\text { negatively? }\end{array}$} & Yes & 100 \\
\hline & No & 0 \\
\hline \multirow{5}{*}{$\begin{array}{l}\text { 5. What are some effects } \\
\text { of oil leakage, if your } \\
\text { answer to the above is } \\
\text { Yes? }\end{array}$} & $\begin{array}{l}\text { Loss of crops and aquatic } \\
\text { animals (especially } \\
\text { fishes) }\end{array}$ & 19.4 \\
\hline & $\begin{array}{l}\text { Destruction of farmland } \\
\text { and loss and } \\
\text { disfiguration of the } \\
\text { mangrove species } \\
\text { vegetation. Loss of the } \\
\text { riparian zone; unsuitable } \\
\text { for agriculture }\end{array}$ & 23.7 \\
\hline & Water and air pollution & 98.6 \\
\hline & $\begin{array}{l}\text { Loss of source of } \\
\text { livelihood and forced } \\
\text { change of business }\end{array}$ & 7.3 \\
\hline & $\begin{array}{l}\text { Reduced food supply } \\
\text { (especially sea foods } \\
\text { such as periwinkles) }\end{array}$ & 2.2 \\
\hline \multirow{2}{*}{$\begin{array}{l}\text { 6. Was your health or that } \\
\text { of a member of your } \\
\text { family affected? }\end{array}$} & Yes & 57.9 \\
\hline & No & 42.1 \\
\hline \multirow{5}{*}{$\begin{array}{l}\text { 7. If your answer above } \\
\text { (6) is Yes, please } \\
\text { mention some of these } \\
\text { health effects }\end{array}$} & $\begin{array}{l}\text { Digestive problem, } \\
\text { including abdominal } \\
\text { pain }\end{array}$ & 32.2 \\
\hline & Cough and nasal problem & 8.3 \\
\hline & $\begin{array}{l}\text { Cardiovascular problem, } \\
\text { including problem with } \\
\text { breathing and cough }\end{array}$ & 28.1 \\
\hline & Vomit, general sickness & 21.6 \\
\hline & Depression & 3.1 \\
\hline
\end{tabular}

Except question 1, which exhibited significant differences $(p<0.05)$ in the responses of the different educational group with the 'Yes' option, there was no significant difference in the perceptions rate for the responses by either gender, income group or level of education

since studies have showed that shallow well water is an important source of domestic water in most rural parts of Nigeria (Eludoyin et al. 2004; Allen 2013). In addition, Table 3 also shows that many respondents complained of 


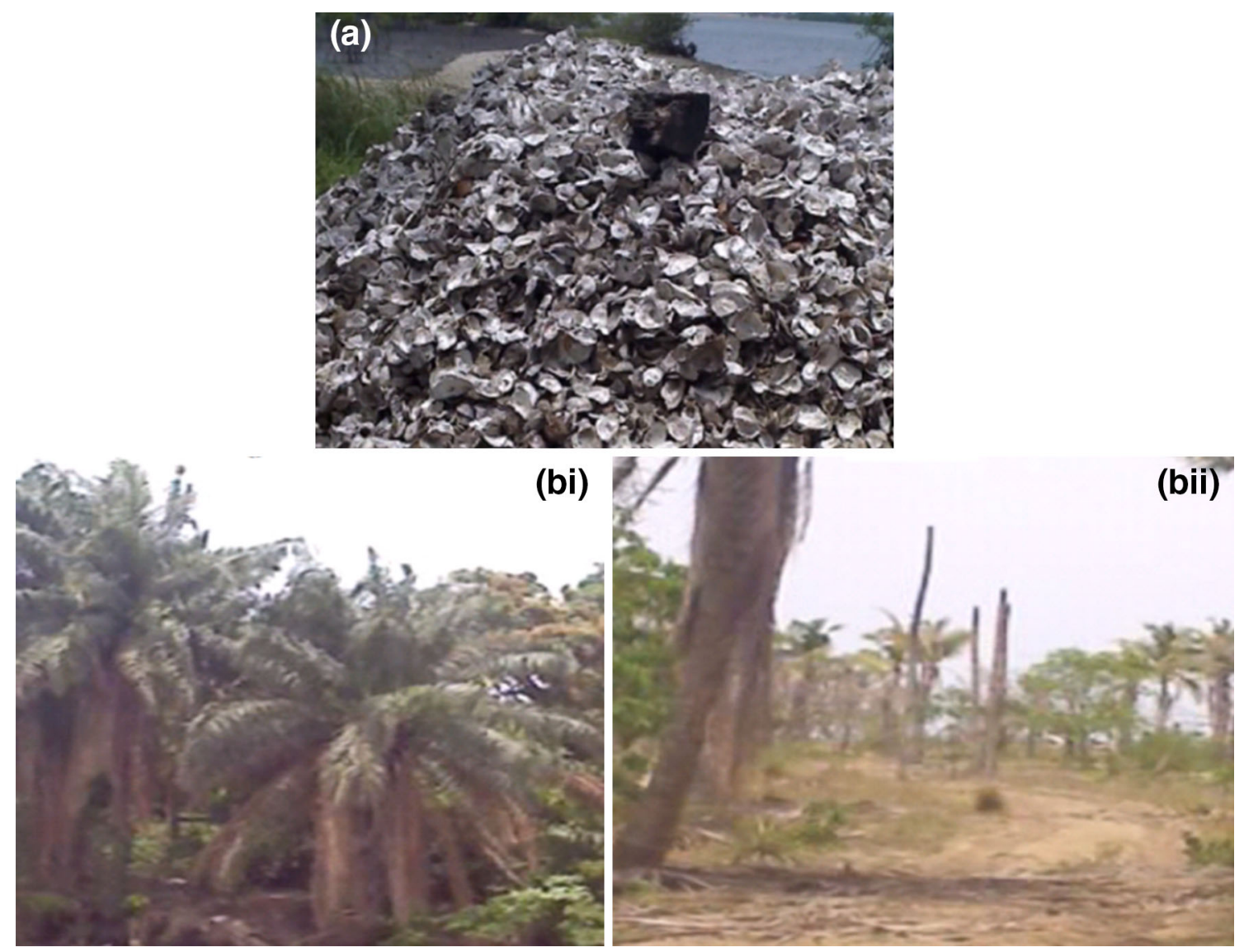

Fig. 3 Some effects of the pipeline explosion of December 2006 in Ilado-Odo community. a Shells of burnt molluscs, (bi) burnt palm trees and (bii) exposed land surface after the vegetation was burnt. Images were taken in June 2007

health problems, especially digestive $(32.2 \%)$, nasal or breathing $(28.1 \%)$ and general sickness $(26.6 \%)$, after consuming water from the wells in the study area. Significant proportion of the respondents also linked the aftermath of the pipeline explosion to destruction of farmlands and crops $(23.7 \%)$ and deaths of aquatic life $(98.8 \%)$.

Ecological effects of the petroleum pipeline explosion

The in-situ physical assessment showed that the pipeline explosion caused deaths of both terrestrial and aquatic animals, including the Phylum Mollusca (or Mollusks), which are known as an important food source for humans (Fig. 3a). Mollusks can also be a carrier of food poisoning from toxins that accumulate in them when contaminated (Astorg et al. 2004). Other effects include burning and destruction of plants and land degradation in general (Fig. 3bi, bii). This is apart from the reported 250 humans that were killed (Adeniyi 2007) and unreported deaths of domestic and wild animals.

Furthermore, our ecological investigations of the species samples from quadrats in the affected or impaired sites and the quadrat at the control sites $(2 \mathrm{~km}$ away from the impaired sites) showed that the population and structure (in terms of height and girth sizes) of identified species (Mangifera indica, Rhizophora mangle, Cocos nucifera and Phoenix spp) were significantly lower in the study area than what was obtained in the control sites (Fig. 4ai-biv). In terms of the identified herbs, the population of common plant species, such as Ananas comosus, Sacciolepis Africana, Oryza longistaminata, Laportea ovalifolia and Pennisetum purpureum, were smaller in the study area than in the control (Fig. 5). In addition, the average species (Shannon-Weiner index) at the control site was 0.68 compared with mean value of 0.37 at the sites within the $500 \mathrm{~m}$ buffer of the pipeline corridor. Mean plants densities (woody and herbs) and the total number of species were also more in the control site than in the study area (Table 4). When we compared rectified and classified imageries for 2005 (June) and 2007 (June), periods before and after the pipeline explosion, we found that more than $15 \%$ of the entire light and heavy forests have been lost (Fig. 6a, c), and we think that this was due to the pipeline fire in December 2006. There was also a corresponding decrease in the exposed or open land area by about 445.5 hectares or $6 \%$ from the land area in 2005 (Fig. 6c). 
(ai)

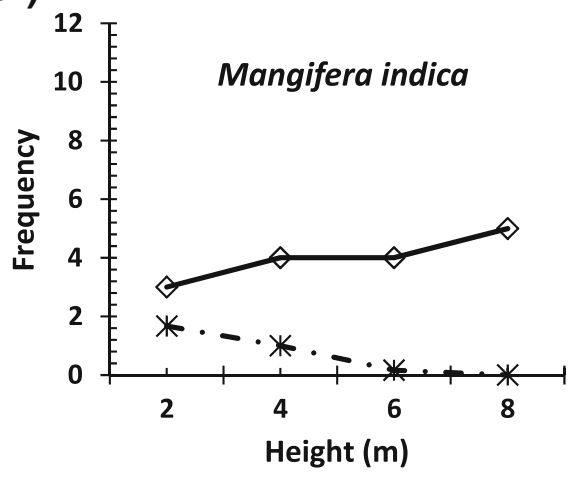

(aii)

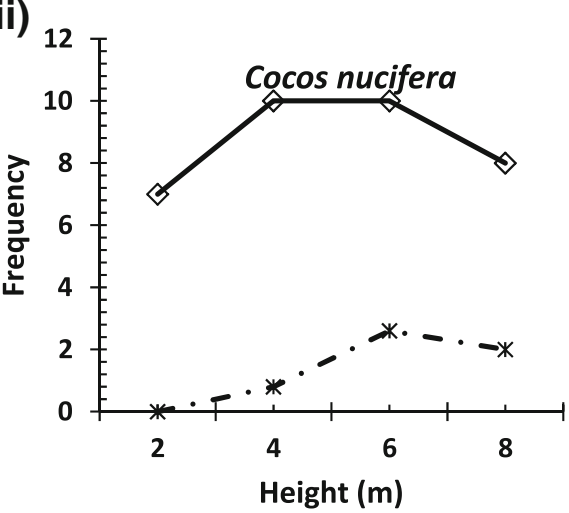

(aiii)

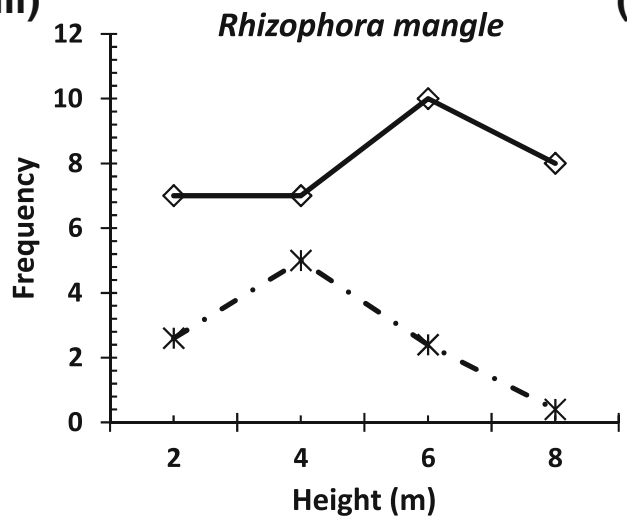

(aiv)

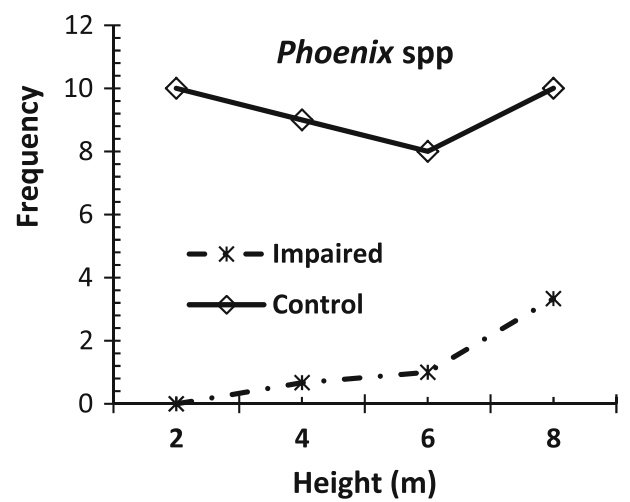

(bi)

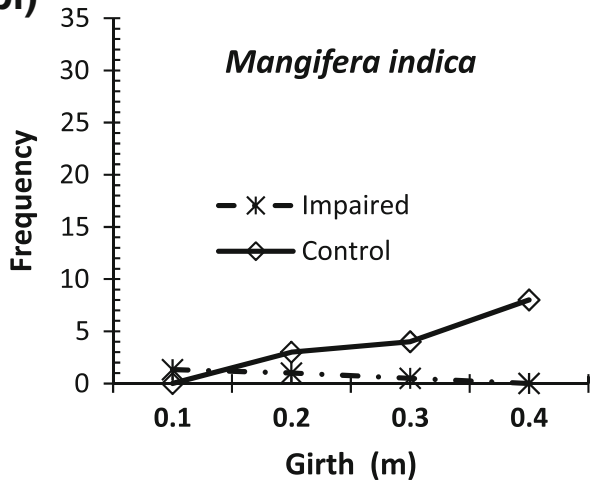

(bii)

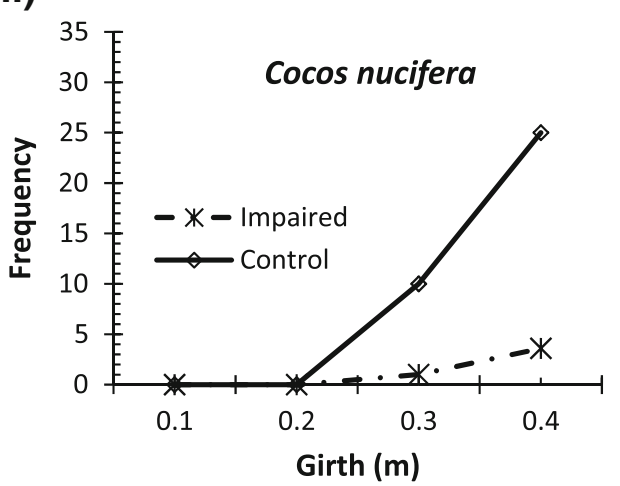

(biii)

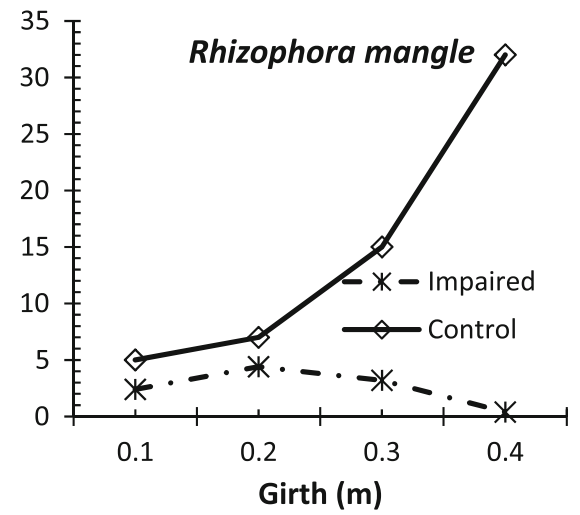

(biv)

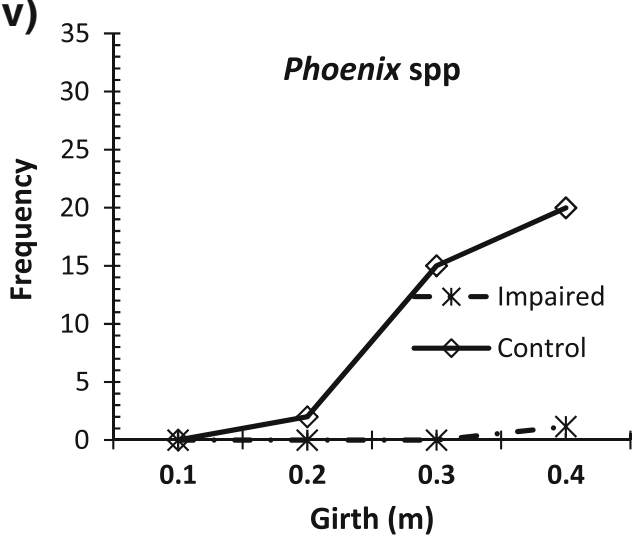

Fig. 4 Mean frequency distributions of identified woody species [by height (ai-aiv) and girths (bi-biv)] within 500 m of the pipeline range ('impaired') and the 'control' quadrats ( $2 \mathrm{~km}$ away) by heights distribution. The values were joined together with lines for easy visualisation 
The objectives of this study were to examine the causes and effects of a pipeline explosion in Nigeria. We examined the December 2006 pipeline fire in Ilado-Odo community as a case study because it was relatively recent, widely reported in local and international news media and had immediate devastating effects, and the area was accessible for study. Our methodology comprises social, field and spatial analyses as improvement over many overly social or laboratory inclined studies.

Our study showed that the right-of-way regulation for the pipeline corridor of the Nigerian Oil Pipeline Act (Chapter 338 LFN, 1990) was violated more than a year before the pipeline explosion, because settlements (Inuegbe clan) were shown by satellite imagery to exist within the pipeline corridor. We do not understand why these settlements were allowed to be there if the pipeline network was well monitored and managed. Similarly, our social investigation showed that the pipeline had probably been punctured somewhere at the epicentre of the explosion and that some people were draining petroleum through hand-dug shallow depression that they created to contain the oil (Fig. 7). While we agree that the QL can be accepted on a long run as an important attribute of the cause of the pipeline explosion in the study area, we attribute the immediate causes to poor pipeline management and probably poor awareness of the danger of exposure to petroleum pipelines in the community. Muhlbauer (2003) explained that 'distance of concern' for pipelines depends on many factors, including the content and size of the pipeline. Different distances were also recommended for different population type ('hard-to-evacuate facilities'; such as schools, hospitals, elderly and handicapped facilities, prisons and areas of public assembly) (Muhlbauer 2003). We found that the Nigerian Pipeline Act did not consider population type and the different population levels of vulnerability and diameters of facilities or landuse around petroleum pipeline in its stipulation of the setbacks to these pipeline facilities. Secondly, we think that the poor social infrastructure (transportation, communication and health) better explains the pipeline fire disaster in the study area than the QL concept. Studies (e.g. Haklar and Dresnack 1999; Muhlbauer 2003) showed that efficient pipeline management strategies should include facilities for accident emergency such as a dedicated phone number for the public to provide emergency information, efficient leak detection system and public awareness.

The effects of the pipeline fire in the study area are both direct human and ecological. The direct human effects include the reported cases of health problems, forced emigration and destruction of the livelihood in the affected community. The impact of these direct human effects can be severe on the people, especially in countries (such as Nigeria) where insurance for medical treatment and loss of livelihood, or any other welfare systems are unavailable for

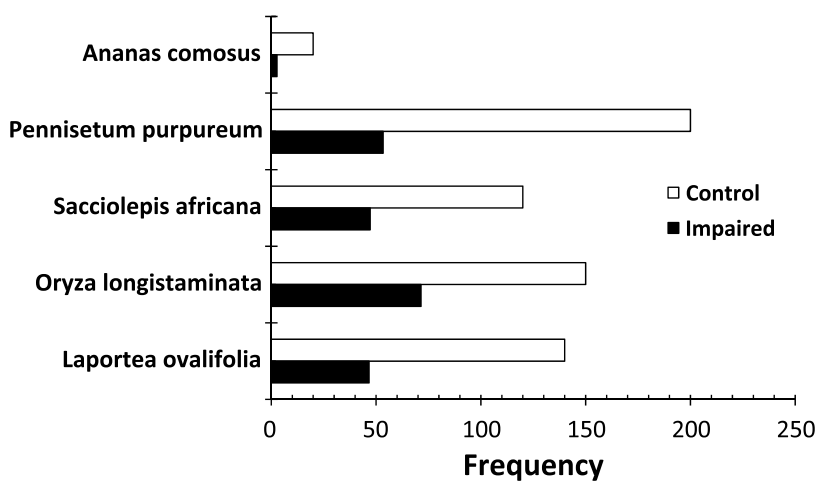

Fig. 5 Frequency distribution of identified herbaceous species within the $500 \mathrm{~m}$ of the pipeline corridor ('impaired') and the 'control' quadrats

Table 4 Relative ecological status of the 'impaired' (0-500 m from the pipeline) and 'control' ( $2 \mathrm{~km}$ from the pipeline) quadrats

\begin{tabular}{|c|c|c|}
\hline Variables & $\begin{array}{l}\text { Control ( } 2 \mathrm{~km} \\
\text { away from } \\
\text { pipeline corridor) }\end{array}$ & $\begin{array}{l}\text { Impaired quadrat } \\
\text { (0-500 m away from } \\
\text { pipeline corridor) }\end{array}$ \\
\hline $\begin{array}{l}\text { Woody plant density } \\
\text { (stem/ha) }\end{array}$ & 13,900 & $1,488.9$ \\
\hline $\begin{array}{l}\text { Herbaceous plant } \\
\text { density (herb/ha) }\end{array}$ & 61,000 & 14,440 \\
\hline 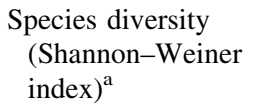 & $0.6,758$ & $0.37(0.16)$ \\
\hline Total specie & 139 & 134 \\
\hline $\begin{array}{l}\text { Relative abundant } \\
\text { woody plant } \\
\text { species (first three) }\end{array}$ & $\begin{array}{l}\text { Phoenix spp } \\
\quad(31.1 \%) \\
\text { Rhizophora } \\
\text { mangle }(26.9 \%) \\
\text { Magnifera indica } \\
(12.6 \%)\end{array}$ & $\begin{array}{l}\text { Rhizophora mangle } \\
\quad(45.2 \%) \\
\text { Phoenix spp }(26.1 \%) \\
\text { Ananas comosus } \\
\quad(14.8 \%)\end{array}$ \\
\hline $\begin{array}{l}\text { Relative abundant } \\
\text { herb species (first } \\
\text { three) }\end{array}$ & $\begin{array}{l}\text { Pennisetum } \\
\text { purpureum } \\
(32.8 \%) \\
\text { Oryza } \\
\text { longistaminata } \\
(24.6 \%) \\
\text { Laportea } \\
\text { ovalifolia } \\
(22.9 \%)\end{array}$ & $\begin{array}{l}\text { Oryza longistaminata } \\
\quad(38.5 \%) \\
\text { Laportea ovalifolia } \\
\quad(28.9 \%) \\
\text { Sacciolepis ovalifolia } \\
\quad(25.4 \%)\end{array}$ \\
\hline
\end{tabular}

${ }^{a}$ Standard deviation of the species index for the impaired quadrats is in parenthesis

most populations (Cardona 2003). Ecological effects showed in this study include significant loss of the vegetal (by about $22 \%$ of the heavy forest and $15 \%$ of light forest) and the exposure of the land surface to erosion (445.5 ha). There was also destruction of many animal and human habitats by the pipeline fire. Effects of fire on the ecosystem have been widely reported in the literature (Floyd 1976; Raison 1979; Pyne et al. 1999; Certini 2005). 
(a) Land use/land cover in 2005

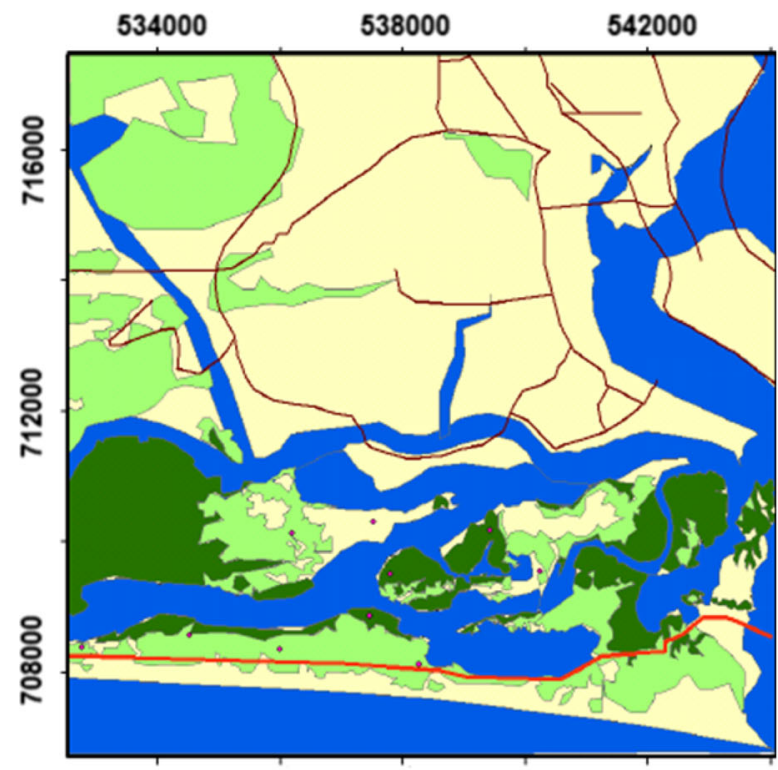

(b) Land cover/Land use in 2007

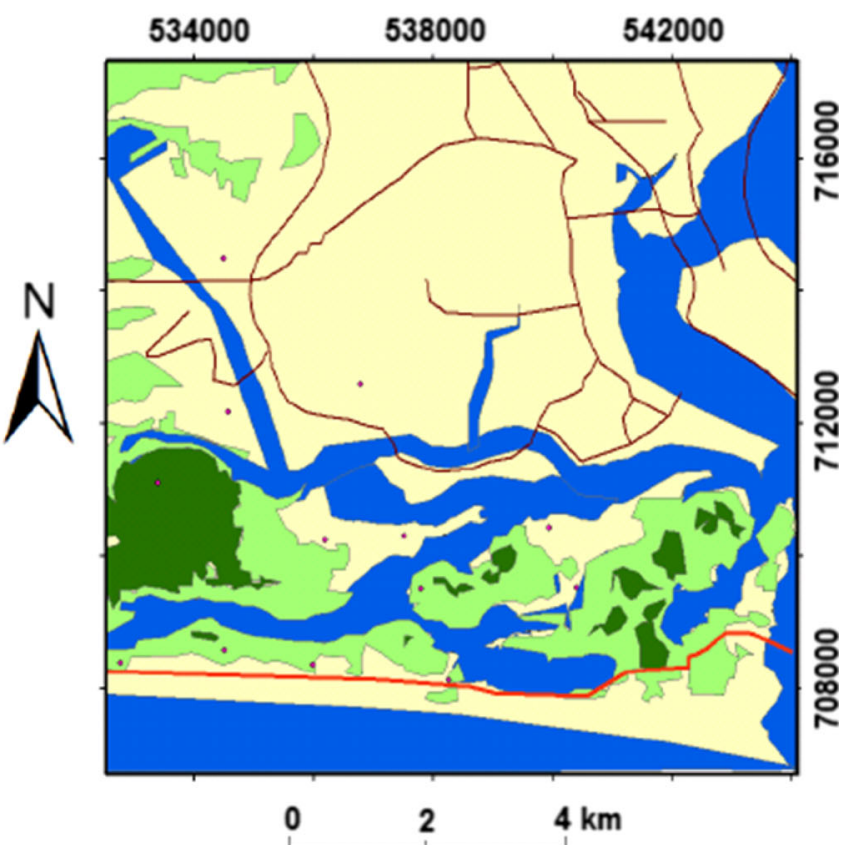

Exposed land surface/Built up area

Surface water - Petroleum pipeline

Light forest - Road

High forest . Settlement (clan)

(c) Percentage change in selected land cover in 2007 (from 2005)

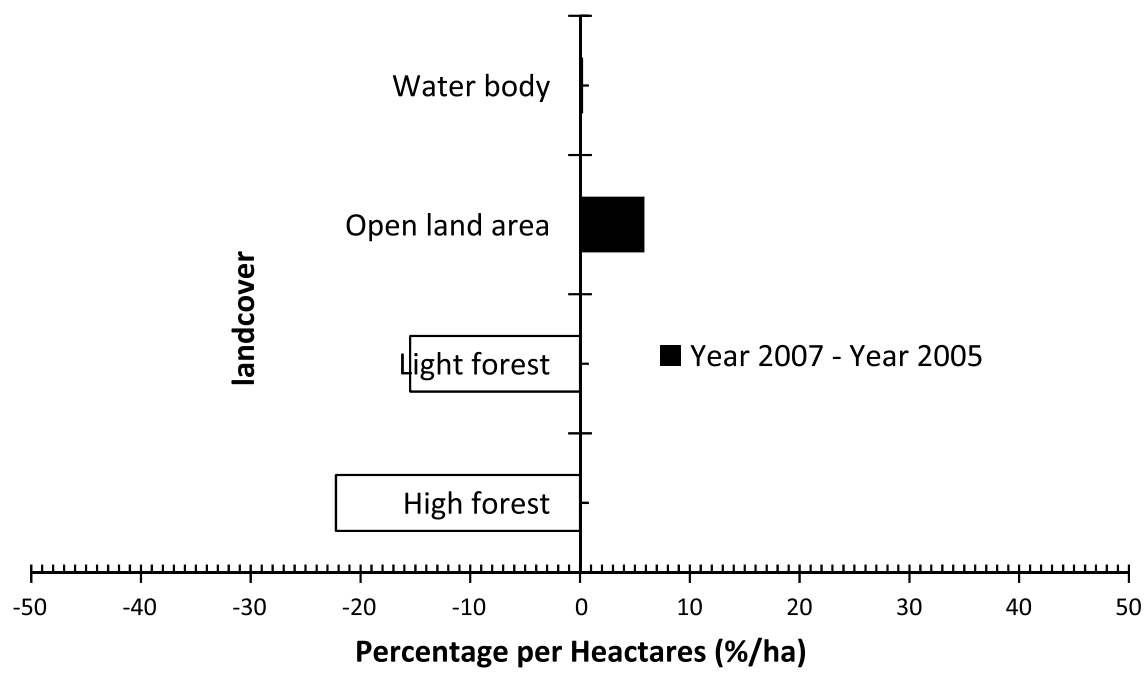

Fig. 6 Landcover/landuse change before (2005) and after (2007) the pipeline explosion; a, b landcover maps for 2005 and 2007 , respectively. c The percentage change in the 2 years

Fire is generally considered as a powerful and rapidly acting modifier of the environment, which when unintended can be a destructive force (Raison 1979). The pipeline fire in the study area was destructive to the human population, terrestrial and aquatic resources. It was also implicated for medical cases of reported by the sample population. Fadeyibi et al. (2011) in a study of the epidemiology of the victims of pipeline fire in Nigeria between 1999 and 2004 showed that majority of the victims sustained more than $60 \%$ body surface burns.

Furthermore, we have noted in this study that more than 256 deaths were recorded immediately after the pipeline fire, and when we consider other pipeline fires with similar massive casualties (Fadeyibi et al. 2011), we found some 


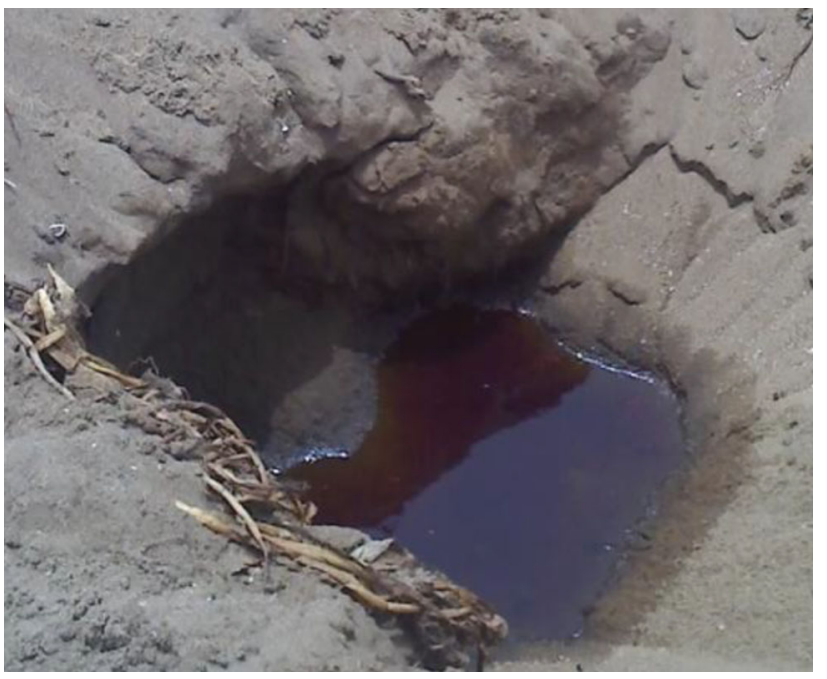

Fig. 7 Image of a hand-dug shallow depression near the punctured petroleum pipeline in Ilado-Odo community, Lagos, Nigeria, in December 2006. A bowl was put in this depression, just below the centre of a ruptured petroleum pipe to contain spilling oil

similarities. High proportion of the victims either lived too close to the pipeline corridor or they were at the epicentre of fire, probably participating to drain the leaking oil. Responses were also often delayed, probably as a result of poor communication or transportation link between the disaster response unit and the disaster zones (Onuoha 2007, 2009). Another problem is poor health facility, including ambulance services that are not socially (for everyone, poor or rich) provided (Onuoha 2009).

\section{Conclusion}

This study has shown both human and spatial dimensions to the understanding of the effects of pipeline explosion to affected communities in Nigeria from a combined use of spatial and social survey methods. Basic problems identified with disasters management identified poor pipeline monitoring and disaster awareness in the society. The pipeline disaster showed a significant link between the social infrastructure, information and the protection of the critical infrastructure. We think that improvement in communication between the local communities that are close to locations of critical infrastructure, as well as improvement in transportation, communication, insurance and medical infrastructure is necessary to ensure efficient protection of the critical infrastructure and reduce the occurrence of such disasters in a long-term plan. While we agree that the present amnesty programmes of the Federal government of Nigeria, which includes payments to the former militants to guide the petroleum pipeline against potential saboteurs (Aghedo 2012; Osumah 2013), we do not think that it will record a long-term success for two reasons. Firstly, the practice of payment former militants to provide protection to a critical infrastructure can provide instruments of social climbing or a means to accumulate wealth and power as explained in concept of the QL in organised crimes (Layman and Potter 2007). Secondly, such payments of individuals or group negate the principle of collective responsibility inherent in participatory monitoring of critical infrastructure, including the petroleum pipelines.

\section{References}

Acosta LJ, Murphy P, McCormick GE, Reese C (2013) Colombia's No. 2 oil pipeline shut after bomb attacks: ecopetrol, Reuters, Mon 7 Oct 2013 11:25 am. Accessed 19/11/2013

Adegboyega AI, Adesola AS (2013) The gains and pains of the amnesty programme in the Niger Delta region of Nigeria, 2007-2012: a preliminary assessment. J Asian Afr Stud 48(4):506-520

Adeniyi O (2007) Playing with fire! (1). This day, January 18, 72

Aghedo I (2012) Winning the war, losing the peace: amnesty and the challenges of post-conflict peace-building in the Niger Delta, Nigeria. J Asian Afr Stud 48(3):267-280

Allen AA (2013) Population dynamics and infrastructure: meeting the millennium development goals in Ondo State, Nigeria. Afr Popul Stud 27(2):229-237

Anifowose B, Damian M, Lawler D, Chapman L (2011) Attacks on oil transport pipelines in Nigeria: a quantitative exploration and possible explanation of observed patterns. Appl Geogr 32:636-651

Astorg P, Arnault N, Czernichow S, Galan P, Hercberg S (2004) Dietary intakes and food sources of $n-6$ and $n-3$ PUFA in French adult men and women. Lipids 39(6):527-535

Asumi J (2009) Blood oil in the Niger Delta. Special Report 229, United States Institute of Peace, p 20

Briggs DJ, Forer P, Jarup L, Stern R (2002) GIS for emergency preparedness and health risk reduction, NATO Science Series, Earth and Environmental Sciences, vol 11, p 344

Bunce RGH (1968) Biomass and production of trees in a mixed deciduous woodland: I. Girth and height as parameters for the estimation of tree dry weight. J Ecol 56(3):759-775

Cairncross S (1989) Water supply and sanitation: an agenda for research. J Trop Med Hyg 92:301

Cardona OD (2003) The need for rethinking the concepts of vulnerability and risk from a holistic perspective: a necessary review and criticism for effective risk management. In: Bankoff G, Frerks G, Hilhost D (eds) Mapping vulnerability: disasters, development and people. Earthscan, London

Certini G (2005) Effects of fire on properties of forest soils: a review. Oecologia 143:1-10

Chokor BA (2004) Perception and response to the challenge of poverty and environmental resource degradation in rural Nigeria: case study from the Niger Delta. J Environ Psychol 24(3):305-318

Clinton WJ (1996) Executive order 13010 - critical infrastructure protection. In: Peters G, Woolley JT (eds) The American Presidency Project http://www.presidency.ucsb.edu/ws/?pid=53066, p 5

Dada FAO, Jibrin GM, Ijeoma A (2008) Macmillan Nigeria secondary atlas. Macmillan Nigeria, Ibadan

Dawotola AW, van Gelder PHAJM, Vrijling JK (2010) Multi criteria decision analysis framework for risk management of oil and gas pipelines. In: Omer B (ed) Reliability, risk and safety. Taylor \& Francis Group, London, pp 307-314

De Bruijne M, Van Eeten M (2007) Systems that should have failed: critical infrastructure protection in an institutionally fragmented environment. J Contingencies Crisis Manag 15:18-29 
Egharevba RK, Osunde DO (2001) The effect of crude oil on seedling growth of two fruit trees: Chrysophllum albidum (Gambay albida) and Dacryodes edulis G. Don. J Sustain Agric 18:25-35

Eludoyin AO, Ofoezie IE, OgunkoyaO O (2004) The effect of Ojatitun market effluent on the chemical quality of receiving OPA reservoir in Ile-Ife, Nigeria. J Environ Manag 72(4):249-259

Eludoyin OM, Adelekan IO, Webster R, Eludoyin AO (2013) Air temperature, relative humidity, climate regionalization and thermal comfort of Nigeria. Int J Climatol. doi:10.1002/joc.3817

ERDAS (1999) ERDAS field guide, 5th edn. Atlanta, Georgia p 698

Fadeyibi IO, Jewo PI, Opoola P, Babalola OS, Ugburo A, Ademiluyi SA (2011) Burns and fire disasters from leaking petroleum pipes in Lagos, Nigeria: an 8-year experience. Burns 37:145-152

Faith DP, Minchin PR, Belbin L (1987) Compositional dissimilarity as a robust measure of ecological distance. Plant Ecol 69(1-3):57-68

Feeley KJ, Gillespie TW, Terborgh JW (2005) The utility of spectral indices from Landsat ETM+ for measuring the structure and composition of tropical dry forests. Biotropica 37(4):508-519

Floyd AG (1976) Effect of burning on regeneration from seeds in wet sclerophyll forest. Aust For 39(3):210-220

Gers C, Schmidt E (2001) Using SPOT 4 satellite imagery to monitor area harvested by small scale sugarcane farmers at Umfolozi. Proc S Afr Sugarcane Technol Assoc 75:28-33

Haklar JS, Dresnack R (1999) Safe separation distances from natural gas transmission pipelines. J Pipeline Saf 1(1):3-20

IBM (2011) IBM SPSS statistics 20 brief guide. IBM Corporation, p 170

Idemudia U, Ite UE (2007) Demystifying the Niger Delta conflict: towards an integrated explanation. Rev Afr Polit Econ 33(109):391-406

Ikporukpo BCO (1988) Managing oil pollution in Nigeria. In: Sada PO, Odemerho FO (eds) Environmental issues and management in Nigerian development. Evans Brothers Ltd, Nigeria, pp 224-229

Iloeje NP (1981) A new geography of Nigeria. Longman Nig. Ltd, Ikeja

Imevbore AMA, Odu CA (1985) Environmental pollution in the Niger Delta. In: Wilcox BHR, Powel CB (eds) Proceedings of a workshop on the mangrove ecosystem of the Niger Delta University of Port-Harcourt, Nigeria, 19-23 May, pp 133-155

Incardona JP, Collier TK, Scholz NK (2010) Oil spills and fish health: exposing the heart of the matter. J Expo Sci Environ Epidemiol. doi:10.1038/jes.2010.51

Isichei AO, Ero H (1987) Responses of savanna to stress and disturbance-the beginning of desertification. In: Sagua VO, Enabor EE, Kio PRO, Ojanuga AU, Mortimore M, Kalu AE (eds) Ecological disasters in Nigeria: drought desertification. Federal Ministry of Science and Technology, Lagos, Nigeria, pp 78-92

Isumonah VA (2013) Armed society in the Niger Delta. Armed Forces Soc 39(2):331-358

Jike VT (2004) Environmental degradation, social disequilibrium, and the dilemma of sustainable development in the Niger-Delta of Nigeria. J Black Stud 34(5):686-701

Kleyer M, Dray S, Bello F, Lepš J, Pakeman RJ, Strauss B, Thuiller W, Lavorel S (2012) Assessing species and community functional responses to environmental gradients: which multivariate methods? J Veg Sci 23:805-821

Li R, Zhou F, Niu X, Di K (2007) Integration of Ikonos and QuickBird imagery for geopositioning accuracy analysis. Photogramm Eng Remote Sens 73(9):1067-1074

Lindley A (2013) Displacement in contested places: governance, movement and settlement in the Somali territories. J East Afr Stud 7(2):291-313

Lyman MD, Potter GW (2007) Chapter 2: theories of organized criminal behavior. In: Gandhirajan CK (ed) Organized crime, 4th edn. Prentice Hall, Englewood Cliffs, pp 59-83

Maselli F, Claudio C, Petkov L (1994) Use of probability entropy for the estimation and graphical representation of the accuracy of maximum likelihood classifications. ISPRS $\mathrm{J}$ Photogramm Remote Sens 49(2):13-20

Moe CL, Rheingans RD (2006) Global challenges in water, sanitation and health. J Water Health 4:41

Muhlbauer KW (2003) Pipeline risk management manual: ideas, techniques, and resources, 3rd edn. Gulf Professional, Houston p 395

Nigerian National Petroleum Corporation, NNPC (2013) Oil production. http://www.nnpcgroup.com/NNPCBusiness/UpstreamVen tures/OilProduction.aspx. Accessed on 18/11/2013

Okoli A, Chukwuma I, Orinya S (2013) Oil pipeline vandalism and Nigeria's national security. Glob J Hum Soc Sci 13(5):67-75

Omeje K (2005) Oil conflict in Nigeria: contending issues and perspectives of the local Niger Delta people. New Polit Econ 10(3):321-334

Onuoha CF (2007) Poverty, pipeline vandalisation/explosion and human security: integrating disaster management into poverty reduction in Nigeria. Afr Secur Rev 16(2):94-108

Onuoha CF (2009) Why the poor pay with their lives: oil pipeline vandalisation, fires and human security in Nigeria. Disasters 33(3):369-389

Osumah O (2013) No war, no peace: the example of peacebuilding in the post-amnesty Niger Delta region of Nigeria. Afr Secur Rev 22(4):244-263

Oyeku OT, Eludoyin AO (2010) Heavy metal contamination of groundwater resources in a Nigerian urban settlement. Afr J Environ Sci Technol 4(4):201-214

Pyne SJ, Andrew PL, Lavens RD (1999) Introduction to wildland fire. Wiley, New York p 769

Raison RJ (1979) Modification of the soil environment by vegetation fires, with particular reference to nitrogen transformation: a review. Plant Soil 51:73-108

Sanchez-Faddeev H, Pijpe J, van der Hulle T, Meij HJ, van der Gaag KJ, Slagboom PE, Westendorp RGJ, de Knijff P (2013) The influence of clan structure on the genetic variation in a single Ghanaian village. Eur J Hum Genet 21:1134-1139

Seidl M, Simák L (2012) Protection of critical infrastructure. Logist Transp 14(1):82-101

Smith LA, Loza L (1994) Texas turns to GIS for oil spill management. Geogr Inf Syst 4(2):48-50

Smith B, Wilson JB (1996) A consumer's guide to evenness indices. Oikos 76(1):70-82

Thomas SC (1996) Asymptotic height as a predictor of growth and allometric characteristics in Malaysian rainforest trees. Am J Bot 83(5):556-566

Thome K (2001) Absolute radiometric calibration of Landsat 7 ETM+ using the reflectance-based method. Remote Sens Environ 78:27-38

van den Berg H, Mbara TC (2011) Are risks associated with energy pipelines in South Africa appreciated? In: Proceedings of the 30th Southern African transport conference, 11-14 July, 2011, 333-342

Van Western C (2003) Introduction to ILWIS, International Institute for Geo-Information Science and Earth Observation (ITC). http://faculty.ksu.edu.sa/geography-alsaleh/ILWIS/ILWIS3_Intro duction.pdf

White J (2006) Another deadly pipeline explosion in Nigeria, World socialist website, international committee of the fourth international. http://www.wsws.org/articles/2006/dec2006/nige-d29.shtml. Accessed 12/03/2012

Williams WT, Lambert JM (1959) Multivariate methods in plant ecology I. Association-analysis in plant communities. J Ecol 47:83-101

Wunder S (2005) Oil wealth and the fate of the forest: a comparative study of eight tropical countries. Taylor and Francis e-Library, Milton Park, p 432 